\title{
The diversity of Sclerotinia sclerotiorum (Lib.) de Bary isolates from western Poland
}

\author{
Elżbieta Starzycka-Korbas ${ }^{1} \cdot$ Zbigniew Weber $^{2} \cdot$ Marcin Matuszczak $^{1} \cdot$ Jan Bocianowski ${ }^{3} \cdot$ Grzegorz Budzianowski $^{4}$. \\ Michał Stefanowicz ${ }^{4}$ Michał Starzycki ${ }^{1}$ (D)
}

Received: 14 April 2020 / Accepted: 17 November 2020 / Published online: 25 November 2020

(C) The Author(s) 2020

\begin{abstract}
Sclerotinia sclerotiorum (Lib.) de Bary is one of the most dangerous pathogens of rapeseed (Brassica napus L.). Rape plants are infested most often in spring during the flowering phase. The aggressive nature of this fungus as well as its pathogenicity is attributed to its mycotoxin, particularly oxalic acid. Oxalic acid is responsible for the development of acid environment in the plant which triggers off activity of hydrolytic enzymes. The developing crystals of calcium oxalate contribute to destabilisation of pectin compounds found in the cell wall. Moreover, oxalic acid also acts as a suppressor of reactive oxygen forms $\left(\mathrm{H}_{2} \mathrm{O}_{2}\right)$. In this study isolates of the S. sclerotiorum were collected in the years 2012-2014 from three different locations. Collective of isolates described as populations. Two hundred twenty eight (228) isolates of S. sclerotiorum were characterized by evaluation of the total amount of acids produced by the pathogen and at molecular level using Random Amplified Polymorphic DNA (RAPD). Statistical differences were found in acids production by particular S. sclerotiorum isolates collected in the years 2012-2014. Moreover, a relationship was found between acids production and the rate of linear mycelium growth. High similarity between pathogen isolates from the same locality was found using RAPD analysis with twelve primers and small genetic differences between pathogen isolates depending on the place of origin.
\end{abstract}

Keywords AMOVA $\cdot$ Oxalic acid $\cdot$ RAPD $\cdot$ Sclerotinia sclerotiorum

\section{Introduction}

Sclerotinia sclerotiorum (Lib.) de Bary is a fungal pathogen observed worldwide. The fungus infects 408 species from 75 families of dicotyledonous plants (Bolland and Hall 1994). S. sclerotiorum in winter oilseed rape crops causes a disease called stem rot and contributes to significant crop losses.

Michał Starzycki

michals@nico.ihar.poznan.pl

1 Department of Oil Plants, The Plant Breeding and Acclimatization Institute, National Research Institut (IHAR-PIB), Strzeszyńska 36, 60-479 Poznań, Poland

2 Department of Phytopathology, Poznan University of Life Sciences, ul. Dąbrowskiego 159, 60-549 Poznań, Poland

3 Department of Mathematical and Statistical Methods, Poznan University of Life Sciences, Wojska Polskiego, 28, 60-637 Poznań, Poland

4 Plant Breeding Strzelce Ltd., Co., IHAR-PIB Group, Małyszyn Branch, Myśliborska, 81 66-400, Gorzów Wlkp, Poland
Seeds from infested plants are small, poorly developed, so called offal (Kruger 1973; Morrall et al. 1976). Yield losses on unprotected oilseed rape plantations in the years favorable for the development of S. sclerotiorum may reach up to $70 \%$ (Korbas et al. 2015).

Symptoms of stem rot on oilseed rape are most commonly observed on leaves and stems. Initially, white-gray spots are visible on leaves, and later the same symptoms occur in part of the circumference or the whole circumference of the stems and sometimes also of pods. Plants with high infections die prematurely. In the next stage, an abundant white mycelial bloom and black sclerotia are observed inside the stems and pods, and in conditions of high air humidity also on their surface (Kryczyński and Weber 2011).

Acids secreted by the pathogen plays an important role in disease development. High Performance Liquid Chromatographic (HPLC) analysis identified phenolic acids such as: tannic, gallic, oxalic, caffeic, vanillic, ferulic, ocoumeric, chlorogenic, cinnamic acids and gentisic acids but the major component of $S$. sclerotiorum culture filtrates is oxalic acid (Basha et al. 2006). In early stages of infection, 
oxalic acid is accumulated in infected tissues, reducing extracellular $\mathrm{pH}$ to about 4-5. Decreased $\mathrm{pH}$ contributes to an increased activity of enzymes degrading cell wall (Bateman and Beer 1965; Marciano et al. 1983; Maxwell and Lumsden 1970; Guimarães and Stotz 2004). Production of oxalic acid is accompanied by chelation of calcium ions $\mathrm{Ca}^{2+}$ and pectin compounds contained in the cell wall (Smith et al. 1986).

The role of oxalic acid in pathogenesis is indicated by the fact that mutants of $S$. sclerotiorum deprived of the ability to produce oxalic acid are not pathogenic even at the full activity of enzymes degrading cell wall. When these mutants regain their ability to produce oxalic acid, they become pathogenic again (Godoy et al. 1990).

The aim of the study was to characterize the $S$. sclerotiorum population in western Poland and to determine its genetic variability. The study was conducted in three localities with different agro-climatic conditions, i.e., in Borowo (52.12 N, 16.79E) in Wielkopolskie Voivodeship, Małyszyn (52.74 N, 15.17E) in Lubuskie Voivodeship and Bąków (50.96 N, 18.31E) in Opolskie Voivodeship. The population of S. sclerotiorum was characterized at the phenotypic level by evaluation of the total amount of acids produced by the pathogen isolates and at the molecular level by RAPD methods (Random Amplified Polymorphic DNA). The results obtained indicate the level of aggressiveness of S. sclerotiorum and a potential risk of stem rot occurrence on oilseed rape in Poland. Moreover these research may help in understanding of management strategies for Sclerotinia stem rot and select of representative isolates for host resistance test.

\section{Material and methods}

The material for the study were populations of the pathogenic fungus S. sclerotiorum collected in the years 2012-2014 in three localities: in Małyszyn (Lubuskie Voivodeship) - 94 isolates, in Borowo (Wielkopolskie Voivodeship) - 59 isolates and in Bạków (Opolskie Voivodeship) - 75 isolates.

In particular years, after the isolation of pure cultures of S. sclerotiorum, their ability to produce total amount of acids was evaluated in the laboratory. A fragment of the medium with a diameter of about $5 \mathrm{~mm}$ with a ten-day mycelium of a pathogen colony was transferred under aseptic conditions to previously prepared Petri dishes of $90 \mathrm{~mm}$ diameter with PDA medium with an addition of an acidity indicator (bromocresol green in the amount of $100 \mathrm{mg} / 11$ of medium) (Steadman et al. 1994). The cultures were incubated in an airconditioned room at $18{ }^{\circ} \mathrm{C}$ with access to light. After $48 \mathrm{~h}$, the diameter of discoloration caused by the production of acids by the growing hyphae of $S$. sclerotiorum fungus was measured in two repetitions. The obtained results were prepared and ranked using Duncan's test.
Sclerotinia sclerotiorum isolates obtained in 2014 were used to study the relationship between the size of colonies of pathogen isolates and discolorations caused by acid production on medium with acidity indicator. After $48 \mathrm{~h}$ of isolates culturing on PDA medium with bromocresol green, diameters of S. sclerotiorum colonies and diameters of discolorations were measured. The values obtained were used to assess the correlation between these traits using STATISTICA 9 software.

RAPD analysis (Welsh and McClelland 1990; Williams et al. 1990) was used to evaluate genetic variability of S. sclerotiorum isolates collected in 2012 and 2014. Polymorphism studies included: genomic DNA isolation of S. sclerotiorum isolates, PCR (Polymerase Chain Reaction) with 12 Operon RAPD primers (Table 1) and product separation by agarose gel electrophoresis. The primers were selected on the basis of previous tests showing a large variety of amplicons.

The obtained data on the polymorphism of amplification products using RAPD method were used for statistical analysis of similarities by Nei and $\mathrm{Li}$ (1979) and molecular variance (AMOVA) methods (GenStat v. 7.1).

\section{Results}

In each of the three years of the study, a large variation in the production of the total amount of acids was found in the individual isolates of $S$. sclerotiorum, in the tests on Petri dishes with PDA medium with an addition of acidity indicator. In 2012, 26 homogeneous groups were found among 57 pathogen isolates, 27 homogeneous groups were found among 75 tested fungal isolates in 2013, and in 201496 isolates of S. sclerotiorum were analyzed, among which 40 homogeneous groups were specified. The diameters of discolorations

Table 1 Primers used for the RAPD reaction

\begin{tabular}{lll}
\hline No & Primer name & Primer $5^{\prime}-3^{\prime}$ sequence \\
\hline 1 & OPR-01 & TGCGGGTCCT \\
2 & OPR-02 & CACAGCTGCC \\
3 & OPR-03 & ACACAGAGGG \\
4 & OPR-04 & CCCGTAGCAC \\
5 & OPS-01 & CTACTGCGCT \\
6 & OPO-02 & ACGTAGCGTC \\
7 & OPO-04 & AAGTCCGCTC \\
8 & OPO-05 & CCCAGTCACT \\
9 & OPP-01 & GTAGCACTCC \\
10 & OPP-02 & TCGGCACGCA \\
11 & OPP-03 & CTGATACGCC \\
12 & OPP-04 & GTGTCTCAGG \\
\hline
\end{tabular}


resulting from hyphae ability to acidify medium by all pathogen isolates in three consecutive years are presented in the tables (Tables 2, 3, 4).

Additionally, in the group of $S$. sclerotiorum isolates obtained in 2014, the relationship between the size of their colonies and the size of medium discoloration caused by acids production was investigated. The obtained results were analyzed by Pearson's correlation analysis. It was found that there is an almost complete correlation between colony diameters and discoloration diameters. The correlation coefficients for isolates from Małyszyn $r=0.994348$, from Borowo $r=$ 0.998846 and from Bakków $r=0.999507$. The larger diameters of colonies were accompanied by larger diameters of medium discoloration.
The amplification products obtained with twelve RAPD primers for $S$. sclerotiorum isolates obtained in the years 2012-2014 were subjected to similarity analysis according to Nei and Li, and then the similarity dendrogram was prepared.

On the basis of the results obtained in 2012, a large similarity was found between pathogen isolates from the same locality. The isolate from Baków (06BAK/12) and from Małyszyn (02MAL/12) were the most distant genetically (Fig. 1).

In 2013, groups of similarities characteristics for the locality of origin were distinguished after molecular analyses and statistical calculations of 75 isolates of $S$. sclerotiorum used in the study. The isolates obtained from the fields of Małyszyn

Table 2 Evaluation of the ability of $S$. sclerotiorum isolates isolated in 2012 to produce acids in vitro

\begin{tabular}{|c|c|c|c|c|c|}
\hline Isolate $^{a}$ & $\begin{array}{l}\text { Diameter of discoloration }[\mathrm{mm}] \\
\text { of the medium under the influence } \\
\text { of the produced acids }\end{array}$ & Homogeneous groups & Isolate $^{\mathrm{a}}$ & $\begin{array}{l}\text { Diameter of discoloration }[\mathrm{mm}] \\
\text { of the medium under the influence } \\
\text { of the produced acids }\end{array}$ & Homogeneous groups \\
\hline 45MAL/12 & 42.5 & A & 04MAL/12 & 22.5 & MNOPQR \\
\hline 40MAL/12 & 39.5 & $\mathrm{~B}$ & 03BOR/12 & 22.5 & MNOPQR \\
\hline 06BAK/12 & 37.5 & $\mathrm{BC}$ & $10 \mathrm{BOR} / 12$ & 22.5 & MNOPQR \\
\hline 28MAL/12 & 36.0 & $\mathrm{C}$ & 08MAL/12 & 22.0 & NOPQRS \\
\hline 41MAL/12 & 35.0 & $\mathrm{CD}$ & 48MAL/12 & 21.5 & OPQRST \\
\hline 23MAL/12 & 35.0 & $\mathrm{CD}$ & $12 \mathrm{MAL} / 12$ & 21.5 & OPQRST \\
\hline 18MAL/12 & 33.0 & $\mathrm{DE}$ & 03MAL/12 & 21.5 & PQRST \\
\hline 15MAL/12 & 32.5 & DEF & 39MAL/12 & 20.5 & QRSTU \\
\hline 27MAL/12 & 32.5 & DEF & 04BAK/12 & 20.5 & QRSTU \\
\hline 33MAL/12 & 32.0 & $\mathrm{EF}$ & 05MAL/12 & 20.5 & QRSTU \\
\hline 19MAL/12 & 31.0 & EFG & $52 \mathrm{MAL} / 12$ & 20.0 & QRSTU \\
\hline 34MAL/12 & 30.5 & EFG & 01BOR/12 & 20.0 & QRSTU \\
\hline 29MAL/12 & 30.0 & FGH & $16 \mathrm{MAL} / 12$ & 20.0 & QRSTU \\
\hline 11MAL/12 & 30.0 & FGH & 07BOR/12 & 19.5 & RSTUV \\
\hline 20MAL/12 & 29.0 & GHI & $10 \mathrm{BAK} / 12$ & 19.0 & STUVW \\
\hline 26MAL/12 & 27.5 & HIJ & 05BOR/12 & 18.5 & TUVW \\
\hline 14MAL/12 & 26.5 & IJK & 02BOR/12 & 18.0 & UVWX \\
\hline 02BAK/12 & 26.0 & JKL & 06BOR/12 & 18.0 & UVWX \\
\hline 01MAL/12 & 25.5 & JKLM & 10MAL/12 & 17.0 & VWXY \\
\hline 02MAL/12 & 25.0 & JKLMN & $12 \mathrm{BAK} / 12$ & 17.0 & VWXY \\
\hline 49MAL/12 & 25.0 & JKLMN & 09BOR/12 & 16.5 & WXYZ \\
\hline 05BAK/12 & 25.0 & JKLMN & $37 \mathrm{MAL} / 12$ & 16.5 & WXYZ \\
\hline 06MAL/12 & 25.0 & JKLMN & 08BAK/12 & 15.5 & XYZ \\
\hline 24MAL/12 & 25.0 & JKLMN & 09MAL/12 & 15.5 & XYZ \\
\hline 30MAL/12 & 24.5 & JKLMNO & 04BOR/12 & 15.0 & YZ \\
\hline 03BAK/12 & 24.5 & JKLMNO & 07BAK/12 & 15.0 & $\mathrm{YZ}$ \\
\hline 08BOR/12 & 24.5 & KLMNO & 09BAK/12 & 14.5 & $\mathrm{YZ}$ \\
\hline 19MAL/12 & 24.0 & KLMNOP & $11 \mathrm{BAK} / 12$ & 14.0 & $\mathrm{Z}$ \\
\hline 07MAL/12 & 23.0 & LMNOPQ & - & - & - \\
\hline \multicolumn{3}{|c|}{$\mathrm{NIR}_{\alpha 0,05} 2,539,459$} & \multicolumn{3}{|c|}{$\mathrm{NIR}_{\alpha 0,05} 2,539,459$} \\
\hline
\end{tabular}

${ }^{\text {a }}$ Isolates origin: MAL - Małyszyn, BAK - Bąków, BOR - Borowo 
Table 3 Evaluation of the ability of S. sclerotiorum isolates isolated in 2013 to produce acids in vitro

\begin{tabular}{|c|c|c|c|c|c|}
\hline Isolate $^{\mathrm{a}}$ & $\begin{array}{l}\text { Diameter of discoloration [mm] } \\
\text { of the medium under the influence } \\
\text { of the produced acids }\end{array}$ & Homogeneous groups & Isolate $^{\mathrm{a}}$ & $\begin{array}{l}\text { Diameter of discoloration [mm] } \\
\text { of the medium under the influence } \\
\text { of the produced acids }\end{array}$ & Homogeneous groups \\
\hline $08 \mathrm{BOR} / 13$ & 45.50 & A & $35 \mathrm{BAK} / 13$ & 30.50 & MNO \\
\hline $55 \mathrm{BAK} / 13$ & 45.00 & $\mathrm{AB}$ & $38 \mathrm{BAK} / 13$ & 30.50 & MNO \\
\hline $03 \mathrm{BOR} / 13$ & 44.50 & $\mathrm{ABC}$ & $59 \mathrm{BAK} / 13$ & 30.50 & MNO \\
\hline $20 \mathrm{MAL} / 13$ & 43.50 & $\mathrm{ABCD}$ & $16 \mathrm{MAL} / 13$ & 30.50 & MNO \\
\hline $16 \mathrm{BOR} / 13$ & 43.00 & $\mathrm{BCD}$ & $32 \mathrm{BAK} / 13$ & 30.00 & MNOP \\
\hline $22 \mathrm{BOR} / 13$ & 43.00 & $\mathrm{BCD}$ & $29 \mathrm{MAL} / 13$ & 30.00 & MNOP \\
\hline $09 \mathrm{BAK} / 13$ & 42.50 & $\mathrm{CD}$ & 07MAL/13 & 29.50 & NOP \\
\hline $19 \mathrm{MAL} / 13$ & 41.50 & $\mathrm{DE}$ & $11 \mathrm{BOR} / 13$ & 29.50 & NOP \\
\hline $49 \mathrm{BAK} / 13$ & 40.50 & $\mathrm{E}$ & $60 \mathrm{BAK} / 13$ & 29.00 & OPQ \\
\hline $28 \mathrm{BOR} / 13$ & 40.00 & $\mathrm{EF}$ & $29 \mathrm{BAK} / 13$ & 28.00 & PQR \\
\hline $18 \mathrm{BAK} / 13$ & 40.00 & $\mathrm{EF}$ & $20 \mathrm{BOR} / 13$ & 27.00 & QRS \\
\hline $53 \mathrm{BAK} / 13$ & 39.50 & $\mathrm{EF}$ & 04MAL/13 & 27.00 & QRS \\
\hline $47 \mathrm{BAK} / 13$ & 38.00 & FG & $13 \mathrm{BAK} / 13$ & 27.00 & QRS \\
\hline $41 \mathrm{BAK} / 13$ & 37.50 & GH & $24 \mathrm{MAL} / 13$ & 26.50 & RST \\
\hline 06 BOR/13 & 37.00 & GHI & $10 \mathrm{BOR} / 13$ & 26.00 & RST \\
\hline $07 \mathrm{BAK} / 13$ & 36.50 & GHIJ & $17 \mathrm{MAL} / 13$ & 26.00 & RST \\
\hline $02 \mathrm{BOR} / 13$ & 36.50 & GHIJ & $52 \mathrm{BAK} / 13$ & 26.00 & RST \\
\hline $45 \mathrm{BAK} / 13$ & 36.50 & GHIJ & $21 \mathrm{BOR} / 13$ & 25.50 & STU \\
\hline $40 \mathrm{BAK} / 13$ & 36.00 & GHIJ & $15 \mathrm{BAK} / 13$ & 25.50 & STU \\
\hline $23 \mathrm{BOR} / 13$ & 35.50 & HIJK & $14 \mathrm{BOR} / 13$ & 25.50 & STU \\
\hline $22 \mathrm{MAL} / 13$ & 35.50 & HIJK & $08 \mathrm{MAL} / 13$ & 25.50 & STU \\
\hline $05 \mathrm{BOR} / 13$ & 35.00 & IJK & $37 \mathrm{BAK} / 13$ & 25.50 & STU \\
\hline $04 \mathrm{BOR} / 13$ & 35.00 & IJK & $58 \mathrm{BAK} / 13$ & 25.00 & STUV \\
\hline $28 \mathrm{MAL} / 13$ & 35.00 & IJK & $02 \mathrm{BAK} / 13$ & 25.00 & STUV \\
\hline $01 \mathrm{MAL} / 13$ & 35.00 & IJK & $27 \mathrm{BAK} / 13$ & 25.00 & STUV \\
\hline $03 \mathrm{MAL} / 13$ & 34.50 & JK & $17 \mathrm{BAK} / 13$ & 24.50 & TUVW \\
\hline $54 \mathrm{BAK} / 13$ & 34.50 & $\mathrm{JK}$ & $27 \mathrm{BOR} / 13$ & 23.50 & UVWX \\
\hline $11 \mathrm{MAL} / 13$ & 33.50 & KL & $18 \mathrm{BOR} / 13$ & 23.00 & VwX \\
\hline $18 \mathrm{MAL} / 13$ & 33.50 & KL & $15 \mathrm{BOR} / 13$ & 23.00 & VWX \\
\hline $11 \mathrm{BAK} / 13$ & 33.50 & KL & $26 \mathrm{MAL} / 13$ & 23.00 & VWX \\
\hline $02 \mathrm{MAL} / 13$ & 32.00 & LM & $27 \mathrm{MAL} / 13$ & 23.00 & VWX \\
\hline $26 \mathrm{BOR} / 13$ & 32.00 & LM & $44 \mathrm{BAK} / 13$ & 22.50 & WX \\
\hline $09 \mathrm{MAL} / 13$ & 32.00 & LM & $33 \mathrm{BAK} / 13$ & 21.50 & $X Y$ \\
\hline $19 \mathrm{BOR} / 13$ & 31.50 & LMN & $21 \mathrm{BAK} / 13$ & 20.50 & $\mathrm{Y}$ \\
\hline $01 \mathrm{BOR} / 13$ & 31.00 & MNO & $13 \mathrm{MAL} / 13$ & 20.00 & YZ \\
\hline $25 \mathrm{BOR} / 13$ & 31.00 & MNO & $42 \mathrm{BAK} / 13$ & 18.50 & $\mathrm{Z}$ \\
\hline $14 \mathrm{MAL} / 13$ & 30.50 & $\mathrm{MNO}$ & $46 \mathrm{BAK} / 13$ & 15.00 & {[} \\
\hline $04 \mathrm{BAK} / 13$ & 30.50 & $\mathrm{MNO}$ & - & - & - \\
\hline \multicolumn{3}{|c|}{$\mathrm{NIR}_{\alpha 0,05} 1,864,775$} & \multicolumn{3}{|c|}{$\mathrm{NIR}_{\alpha 0,05} 1,864,775$} \\
\hline
\end{tabular}

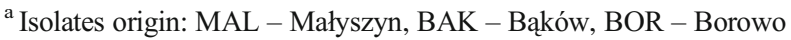

(26MAL/13, 27MAL/13 and 20MAL/13, $28 \mathrm{MAL} / 13$ ) were the most differentiated from each other (Fig. 2).

Results obtained after RAPD and statistical analysis of 96 isolates of S. sclerotiorum isolated in 2014 also indicate a high similarity between isolates from the same locality. The most distant genetic isolates were 34BOR/14 from Borowo and 19MAL/14 from Małyszyn. The isolates from Bąków (33BAK/14, 11BAK/14, 05BAK/14) were also very diverse (Fig. 3).

The analysis of molecular variance (AMOVA) based on RAPD amplification products of S. sclerotiorum isolates showed small differences between pathogen isolates from three different localities in particular years of the study. The greatest differences between fungal populations from different locations were observed in 2012 at the level of 13\% (Table 5).
In the following years the differences were smaller and amounted to 4\% in 2013 and 7\% in 2014 (Tables 6 and 7).

\section{Discussion}

The $S$. sclerotiorum pathogen is a threat to more than 400 dicotyledonous plant species (Bolland and Hall 1994). It is the subject of many studies aimed at a thorough understanding of the mechanisms of pathogenesis and phenotypic and genotypic differentiation of its isolates.

S. sclerotiorum, like many other pathogens, requires an acidic $\mathrm{pH}$ to develop. The acidic environment is produced by the pathogen itself. The following organic acids were identified in S. sclerotiorum cultures and in sclerotial exudates by 
Table 4 Evaluation of the ability of S. sclerotiorum isolates isolated in 2014 to produce acids in vitro

\begin{tabular}{|c|c|c|c|c|c|}
\hline Isolate $^{\mathrm{a}}$ & $\begin{array}{l}\text { Diameter of discoloration [mm] } \\
\text { of the medium under the influence } \\
\text { of the produced acids }\end{array}$ & Homogeneous groups & Isolate $^{a}$ & $\begin{array}{l}\text { Diameter of discoloration }[\mathrm{mm}] \\
\text { of the medium under the influence } \\
\text { of the produced acids }\end{array}$ & Homogeneous groups \\
\hline $30 \mathrm{BOR} / 14$ & 72.00 & A & $44 \mathrm{MAL} / 14$ & 30.00 & UVWX \\
\hline $24 \mathrm{BAK} / 14$ & 70.50 & $\mathrm{AB}$ & $25 \mathrm{MAL} / 14$ & 30.00 & UVWX \\
\hline $14 \mathrm{BAK} / 14$ & 70.00 & $\mathrm{ABC}$ & $17 \mathrm{MAL} / 14$ & 29.50 & VWXY \\
\hline $02 \mathrm{BAK} / 14$ & 70.00 & $\mathrm{ABC}$ & $32 \mathrm{BAK} / 14$ & 29.00 & WXYZ \\
\hline $03 \mathrm{BAK} / 14$ & 70.00 & $\mathrm{ABC}$ & $22 \mathrm{BAK} / 14$ & 28.50 & WXYZ \\
\hline 38 BOR/14 & 70.00 & $\mathrm{ABC}$ & $34 \mathrm{BOR} / 14$ & 27.50 & XYZ[ \\
\hline $08 \mathrm{BAK} / 14$ & 69.50 & $\mathrm{ABCD}$ & $22 \mathrm{BOR} / 14$ & 27.50 & $\mathrm{XYZ}[$ \\
\hline $18 \mathrm{BAK} / 14$ & 68.00 & $\mathrm{BCDE}$ & $06 \mathrm{BOR} / 14$ & 27.50 & XYZ[ \\
\hline $10 \mathrm{BAK} / 14$ & 68.00 & $\mathrm{BCDE}$ & $21 \mathrm{BOR} / 14$ & 26.50 & $\mathrm{YZ} \backslash$ \\
\hline $05 \mathrm{BAK} / 14$ & 67.00 & $\mathrm{CDEF}$ & $31 \mathrm{BAK} / 14$ & 26.00 & $Z[\backslash$ \\
\hline $16 \mathrm{BAK} / 14$ & 66.50 & $\mathrm{DEF}$ & $27 \mathrm{BOR} / 14$ & 26.00 & $Z[\backslash$ \\
\hline $20 \mathrm{BAK} / 14$ & 66.50 & DEF & $18 \mathrm{BOR} / 14$ & 26.00 & $Z[\backslash$ \\
\hline $40 \mathrm{BAK} / 14$ & 66.00 & $\mathrm{EF}$ & $24 \mathrm{MAL} / 14$ & 25.50 & $Z[\rceil]$ \\
\hline $11 \mathrm{BAK} / 14$ & 65.00 & EFG & $13 \mathrm{BOR} / 14$ & 25.50 & $\mathrm{Z}[\mathrm{]}]$ \\
\hline $04 \mathrm{BAK} / 14$ & 65.00 & EFG & $04 \mathrm{MAL} / 14$ & 24.50 & {$[\mathrm{~N}]^{\wedge}$} \\
\hline $21 \mathrm{BAK} / 14$ & 64.50 & FGH & $24 \mathrm{BOR} / 14$ & 24.50 & {$[\mathrm{~N}]^{\wedge}$} \\
\hline $25 \mathrm{BOR} / 14$ & 62.50 & GHI & $16 \mathrm{MAL} / 14$ & 24.50 & {$[\mathrm{r}]^{\wedge}$} \\
\hline $26 \mathrm{BAK} / 14$ & 61.50 & HIJ & $11 \mathrm{BOR} / 14$ & 24.50 & {$[1]^{\wedge}$} \\
\hline $06 \mathrm{BAK} / 14$ & 61.50 & HIJ & $28 \mathrm{BOR} / 14$ & 24.00 & {[]$^{\wedge}$} \\
\hline $34 \mathrm{BAK} / 14$ & 61.50 & HIJ & $14 \mathrm{BOR} / 14$ & 23.50 & $\backslash]^{\wedge} \div$ \\
\hline $19 \mathrm{BAK} / 14$ & 61.00 & IJ & $03 \mathrm{MAL} / 14$ & 23.00 & $\backslash]^{\wedge}{ }_{-}^{-} a$ \\
\hline $25 \mathrm{BAK} / 14$ & 60.50 & IJK & $08 \mathrm{BOR} / 14$ & 23.00 & $1]^{\wedge}{ }_{-}^{-} a$ \\
\hline $28 \mathrm{BAK} / 14$ & 60.50 & IJK & $30 \mathrm{MAL} / 14$ & 22.00 & ]$^{\wedge}-a b$ \\
\hline $07 \mathrm{BAK} / 14$ & 58.50 & $\mathrm{JK}$ & $08 \mathrm{MAL} / 14$ & 21.50 & $\wedge$ abc \\
\hline $30 \mathrm{BAK} / 14$ & 57.50 & KL & $05 \mathrm{MAL} / 14$ & 21.50 & $\wedge^{-} \cdot a b c$ \\
\hline $07 \mathrm{BOR} / 14$ & 55.00 & $\mathrm{~L}$ & $02 \mathrm{BOR} / 14$ & 21.00 & $\wedge^{-} \cdot \mathrm{abcd}$ \\
\hline $38 \mathrm{BAK} / 14$ & 52.00 & M & $35 \mathrm{MAL} / 14$ & 21.00 & $\wedge^{-} \cdot \mathrm{abcd}$ \\
\hline $36 \mathrm{BAK} / 14$ & 47.00 & $\mathrm{~N}$ & $07 \mathrm{MAL} / 14$ & 20.50 & 'abcde \\
\hline $14 \mathrm{MAL} / 14$ & 47.00 & $\mathrm{~N}$ & $38 \mathrm{MAL} / 14$ & 20.00 & 'abcde \\
\hline $13 \mathrm{MAL} / 14$ & 46.00 & $\mathrm{~N}$ & $15 \mathrm{MAL} / 14$ & 20.00 & 'abcde \\
\hline $12 \mathrm{MAL} / 14$ & 46.00 & $\mathrm{~N}$ & $36 \mathrm{BOR} / 14$ & 20.00 & 'abcde \\
\hline $29 \mathrm{BAK} / 14$ & 45.50 & NO & $19 \mathrm{MAL} / 14$ & 19.50 & abcdef \\
\hline $01 \mathrm{MAL} / 14$ & 44.00 & NOP & $20 \mathrm{BOR} / 14$ & 19.50 & abcdef \\
\hline $31 \mathrm{BOR} / 14$ & 42.50 & OP & $21 \mathrm{MAL} / 14$ & 19.50 & abcdef \\
\hline $10 \mathrm{MAL} / 14$ & 42.00 & $\mathrm{P}$ & $35 \mathrm{BAK} / 14$ & 19.50 & abcdef \\
\hline 09 MAL/14 & 41.00 & $\mathrm{P}$ & $29 \mathrm{BOR} / 14$ & 19.00 & bcdefg \\
\hline $37 \mathrm{MAL} / 14$ & 36.50 & $\mathrm{Q}$ & $33 \mathrm{MAL} / 14$ & 19.00 & bcdefg \\
\hline $11 \mathrm{MAL} / 14$ & 36.00 & $\mathrm{QR}$ & $28 \mathrm{MAL} / 14$ & 19.00 & bcdefg \\
\hline $39 \mathrm{MAL} / 14$ & 35.50 & QRS & $05 \mathrm{BOR} / 14$ & 19.00 & bcdefg \\
\hline $34 \mathrm{MAL} / 14$ & 35.50 & QRS & $47 \mathrm{MAL} / 14$ & 18.50 & bcdefg \\
\hline $22 \mathrm{MAL} / 14$ & 35.50 & QRS & $23 \mathrm{BOR} / 14$ & 18.50 & bcdefg \\
\hline $43 \mathrm{MAL} / 14$ & 34.50 & QRST & $02 \mathrm{MAL} / 14$ & 18.00 & cdefg \\
\hline 35 MAL/14 & 34.00 & QRST & $29 \mathrm{MAL} / 14$ & 18.00 & cdefg \\
\hline $39 \mathrm{BAK} / 14$ & 33.00 & RSTU & $46 \mathrm{MAL} / 14$ & 17.50 & defg \\
\hline $42 \mathrm{BAK} / 14$ & 33.00 & RSTU & $45 \mathrm{MAL} / 14$ & 17.00 & efg \\
\hline $40 \mathrm{BOR} / 14$ & 32.50 & STUV & $01 \mathrm{BOR} / 14$ & 16.00 & fgh \\
\hline $50 \mathrm{MAL} / 14$ & 31.50 & TUVW & $26 \mathrm{BOR} / 14$ & 15.50 & $\mathrm{gh}$ \\
\hline $33 \mathrm{BAK} / 14$ & 30.50 & UVWX & $06 \mathrm{MAL} / 14$ & 13.00 & $\mathrm{~h}$ \\
\hline \multicolumn{3}{|c|}{$\mathrm{NIR}_{\alpha 0,05} 2960$} & \multicolumn{3}{|c|}{$\mathrm{NIR}_{\alpha 0,05} 2960$} \\
\hline
\end{tabular}

${ }^{\text {a }}$ Isolates origin: MAL - Małyszyn, BAK - Bąków, BOR - Borowo

HPLC analysis: tannic, gallic, oxalic, caffeic, vanillic, ferulic, o-coumeric, chlorogenic, cinnamic acids and gentisic acids, with the highest amounts determined for oxalic acid (Basha et al. 2006). Similar results were obtained with the study of Sclerotinia ginseng. In sclerotial exudates oxalic acid, gallic acid, ferulic acid, vanillic acid, caffeic acid, and tannic acid were identified (Wang et al. 2018).
Many studies emphasize the role of oxalic acid as necessary in the process of plant infection and pathogenicity index (Hegedus and Rimmer 2005; Godoy et al. 1990; Li et al. 2008a; Williams et al. 2011). During the growth of the fungus, the produced oxalic acid creates an acidic environment in which enzymes destroying the cell wall of plants can be activated (Maxwell and Lumsden 1970; Marciano et al. 1983; 
Fig. 1 Dendrogram of similarity based on polymorphism of RAPD amplification products of S. sclerotiorum isolates obtained from three localities in 2012

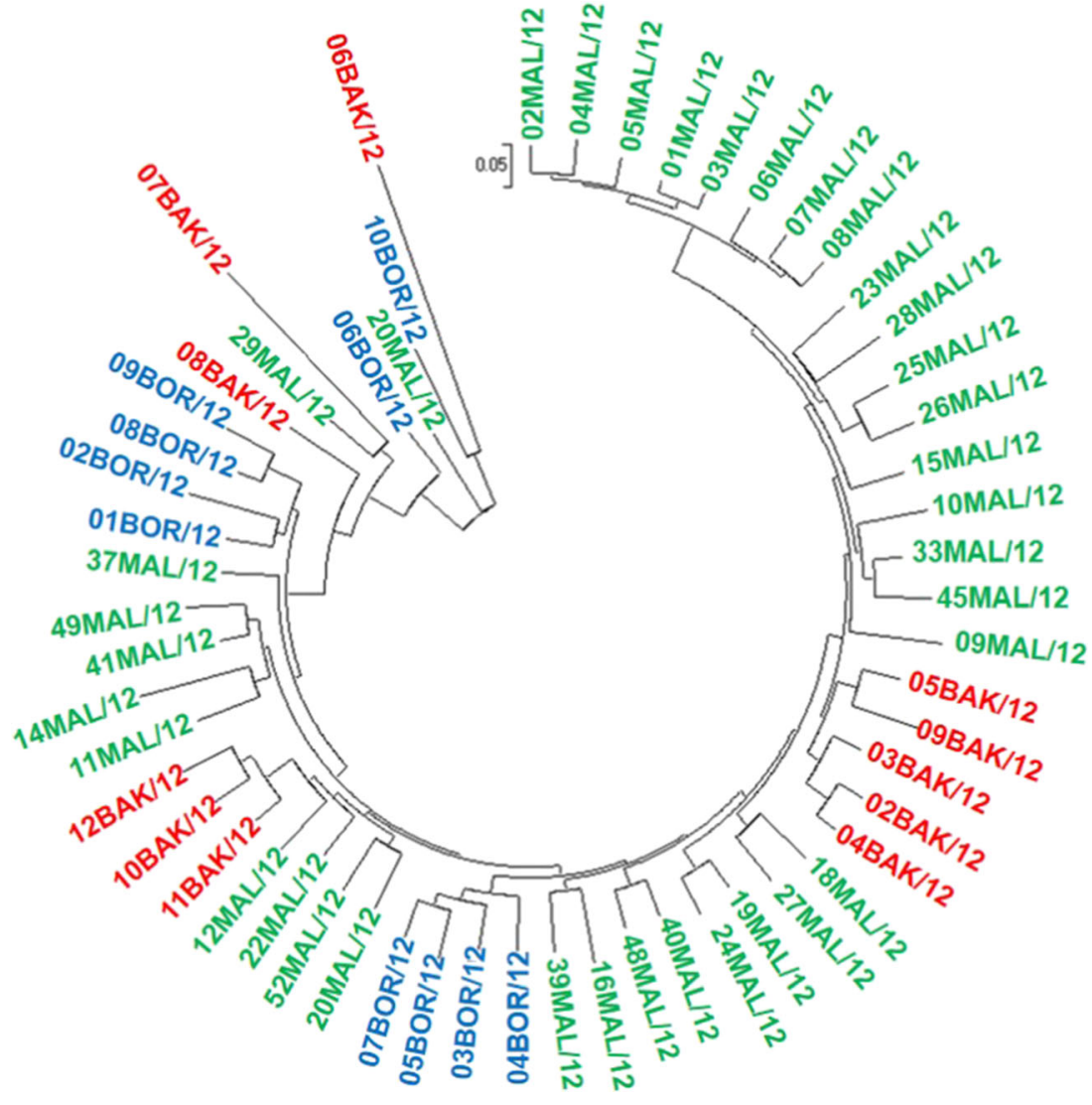

Kim et al. 2008). Oxalic acid with calcium ions lead to the formation of calcium oxalate crystals, contributing to the blocking of plant vascular bundles (Kim et al. 2008), as well as destabilization of pectin compounds contained in the host cell wall, while disturbing its integrity (Bateman and Beer 1965; Maxwell and Lumsden 1970). Moreover, this compound causes abnormal opening of stomata cells and inhibits their closure during infection, leading to wilting of the plant (Guimarães and Stotz 2004; Kim et al. 2008). Oxalic acid also destabilizes the photosynthesis (Fagundes-Nacarath et al. 2018). Damage to the photosynthetic apparatus causes the acidity of $\mathrm{H}_{2} \mathrm{C}_{2} \mathrm{O}_{4}$ as well as $\mathrm{C}_{2} \mathrm{O}_{4}{ }^{2-}$ ions (Yang et al. 2014). Furthermore this toxin limits the removal of reactive oxygen species (free radicals), which are formed as a result of the host's defense reaction (Cessna et al. 2000). Mutants of $S$. sclerotiorum that do not produce oxalic acid are characterized by a lack of ability to infect the plants (Kim et al. 2008). This fact indicates the role of this substance in initiating a number of processes leading to dying of plants in which the pathogen develops.

Considering the important role of oxalic acid in the pathogenesis caused by $S$. sclerotiorum, many studies were conducted in order to detect differences in the production of this acid by isolates of $S$. sclerotiorum fungus occurring in nature.

In each of the three years of the study, a large variation in the production of total amount of acids by individual isolates of S. sclerotiorum was found, in the tests on Petri dishes with PDA medium with an addition of an acidity indicator. In 2012, 26 homogeneous groups were found among 57 pathogen isolates, in 201327 homogeneous groups were found among 75 tested fungal isolates, and 96 isolates of S. sclerotiorum were analyzed in 2014, among which 40 homogeneous groups were found.

A very high diversity of isolates in the production of especially oxalic acid by $S$. sclerotiorum was observed in studies carried out on other plant material (Starzycka et al. 2002; Durman et al. 2005; Starzycka and Starzycki 2011; Mo et al. 2007; Li et al. 2008b; EL-Argawy 2015).

Isolates of $S$. sclerotiorum from China and Poland were tested in the study from 2002 (Starzycka et al. 2002). Out of 16 Chinese isolates, 13 were isolated from infected oilseed rape plants, 2 from sunflower and 1 from sage. Polish pathogen isolates were derived only from oilseed rape. Both in the group of pathogens originating from Poland and China, a very high variability in the production of oxalic acid was found. On the basis of HPLC analysis, it was found that after 3 weeks of pathogen culture the concentration of this acid in the medium ranged from $0.44-3.18 \mathrm{mM}$. The highest and the lowest concentrations of oxalic acid were found in Chinese isolates, which proves that the Chinese fungus population is very diverse in terms of this feature. The concentration of oxalic acid in Polish isolates was in the range of $0.48-0.97 \mathrm{mM}$. No 


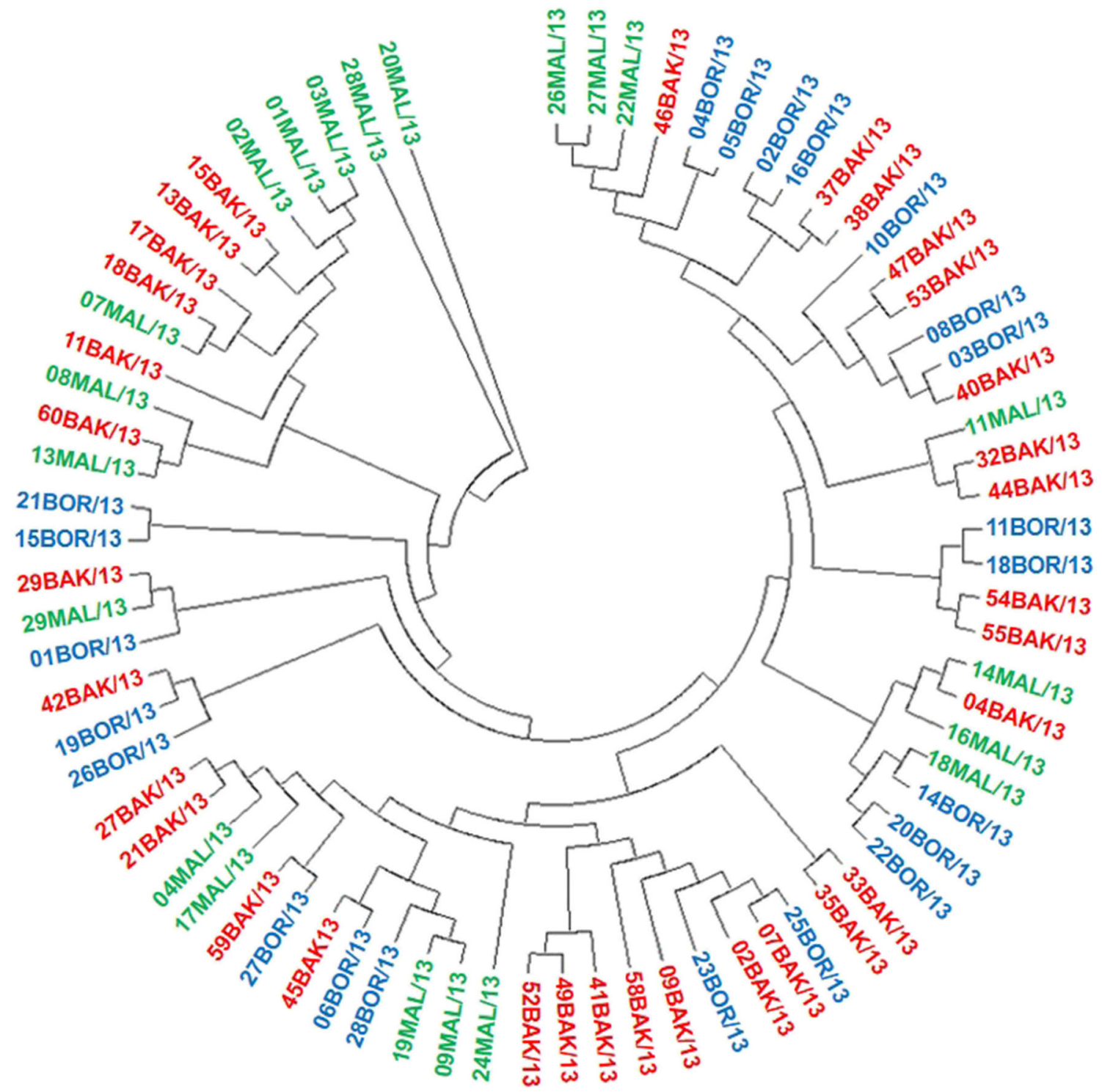

Fig. 2 Dendrogram of similarity based on polymorphism of RAPD amplification products of S. sclerotiorum isolates obtained from three localities in 2013

correlation between the weight of mycelium and the ability of the isolates to produce oxalic acid was found in this study. On the other hand, an almost complete correlation $(r=0.99)$ was found in the study presented between the diameter of colonies of individual isolates of $S$. sclerotiorum and the diameter of medium discoloration caused by the production of oxalic acid by these isolates.

A very large variation in the production of oxalic acid by S. sclerotiorum was also found in 121 fungal isolates from Argentinean soybean, sunflower and lettuce fields, determining 46 homogeneous groups (Durman et al. 2005). It was found after the spectrophotometric analysis that the production of oxalic acid by individual isolates ranged from 18 to $110 \mathrm{mg}$ per mg of dry mass of mycelium. The highest amounts of oxalic acid were produced by isolates originating from soybean.
Among the collected population of $S$. sclerotiorum fungus from oilseed rape fields in Małyszyn, similar results were obtained (Starzycka and Starzycki 2011). In the study on the level of oxalic acid production by 61 pathogen isolates on media with acidity indicator (bromocresol green), 29 homogeneous groups were found. After $24 \mathrm{~h}$ from inoculation in Petri dishes, the highest diameters of discoloration were observed in seven isolates of $S$. sclerotiorum. In addition, a high correlation coefficient $(0.74)$ was found for the level of oxalic acid produced by the same isolates of $S$. sclerotiorum after $24 \mathrm{~h}$ and $120 \mathrm{~h}$ (5 days). In the present study, the production of oxalic acid was evaluated by measuring the diameter of discolorations with $48 \mathrm{~h}$ colonies of S. sclerotiorum on medium with acidity indicator. This was considered the most appropriate time as oxalic acid plays an important role in the initial stages of infection. 


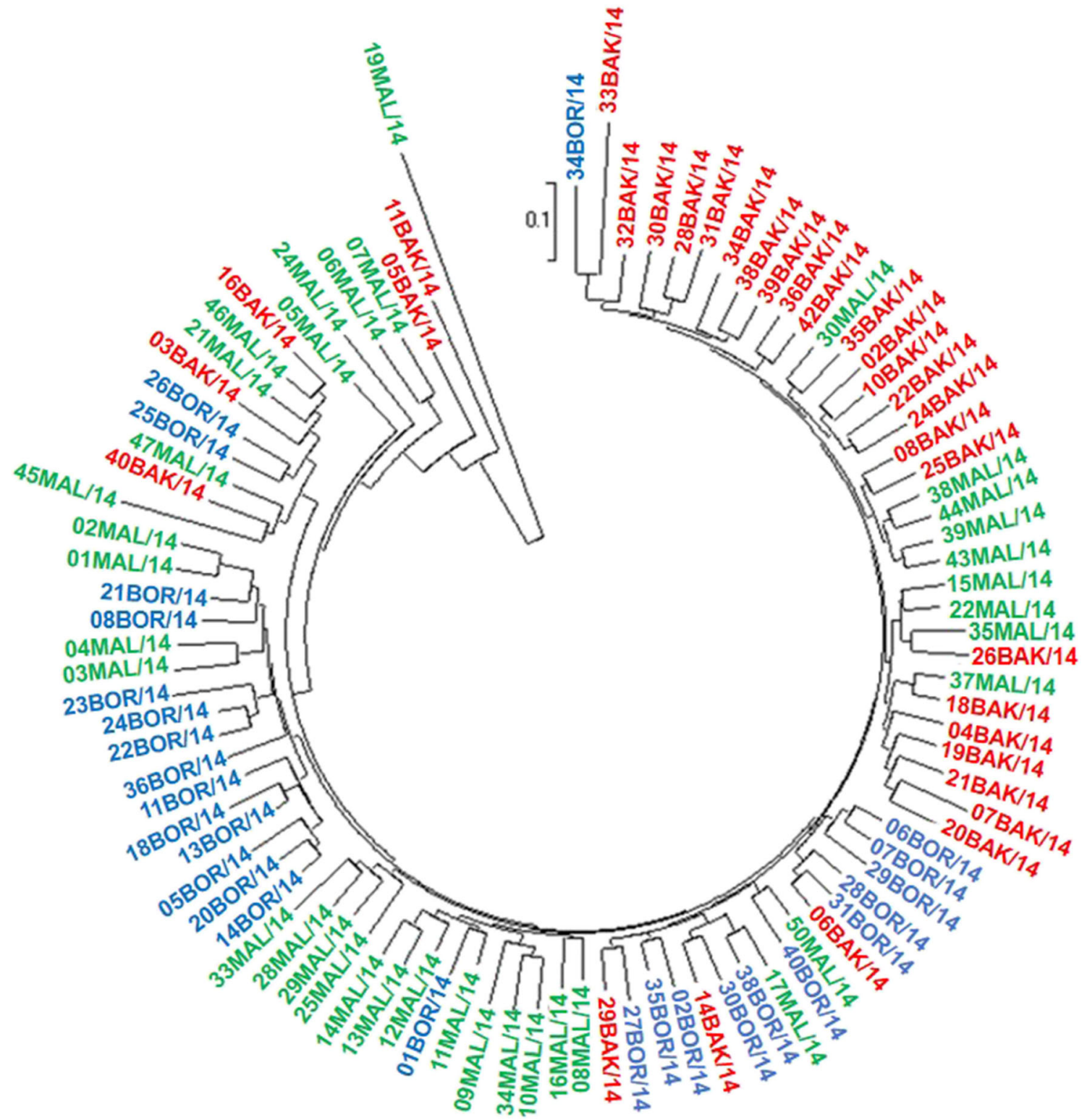

Fig. 3 Dendrogram of similarity based on polymorphism of RAPD amplification products of S. sclerotiorum isolates obtained from three localities in 2014

A large variation not only in terms of oxalic acid production was found in the study conducted by Mo et al. (2007) who analyzed 160 isolates of $S$. sclerotiorum from different parts of the world ( 71 isolates from China, 39 from Canada, 20 from the USA and 30 from England). They also differed in the rate of linear mycelium growth, the number of sclerotia produced and aggressiveness. Additionally, a positive correlation was observed between the concentration of oxalic acid produced at the initial stage of pathogen development and its aggressiveness. The same conclusions were reached by Li et al. (2008b). Correlation analysis showed that in a sample of 205 isolates of S. sclerotiorum from England, Canada and China there was a

Table 5 Molecular variance analysis (AMOVA) based on RAPD markers for S. sclerotiorum isolates obtained from three localities in $2012, p<0.001$

\begin{tabular}{|c|c|c|c|c|c|}
\hline Source & Degrees of freedom & Sum of squares & Mean of squares & Standard deviation & Variance $\%$ \\
\hline Between populations & 2 & 92.639 & 46.319 & 2.112 & $13 \%$ \\
\hline Inside the population & 54 & 768.765 & 14.236 & 14.236 & $87 \%$ \\
\hline Sum & 56 & 861.404 & & 16.348 & $100 \%$ \\
\hline
\end{tabular}


Table 6 Molecular variance analysis (AMOVA) based on RAPD markers for S. sclerotiorum isolates obtained from three localities in $2013, p<0.001$

\begin{tabular}{|c|c|c|c|c|c|}
\hline Source & Degrees of freedom & Sum of squares & Mean of squares & Standard deviation & Variance $\%$ \\
\hline Between populations & 2 & 59.580 & 29.790 & 0.584 & $4 \%$ \\
\hline Inside the population & 72 & 1114.127 & 15.474 & 15.474 & $96 \%$ \\
\hline Sum & 74 & 1173.707 & & 16.058 & $100 \%$ \\
\hline
\end{tabular}

positive correlation $(r=0.739)$ between their aggressiveness and the production of oxalic acid. Similar results were obtained in this study, in which the ability of selected isolates of S. sclerotiorum to produce oxalic acid and their pathogenicity to oilseed rape plants were compared. For the results of the 2013 and 2014, the Pearson's correlation coefficient for these traits was very high $(r=0.73$ and $r=0.82)$, and in 2012 it was almost complete $(\mathrm{r}=0.95)$.

Also the study by EL-Argawy (2015) indicates that the production of oxalic acid is closely related to the degree of S. sclerotiorum pathogenicity. Five isolates from bean crops in the EL-Behra region (Egypt), characterized by different pathogenicity levels, were used in this study. The most pathogenic isolate SS34 produced the highest amounts of oxalic acid $(5.46 \mathrm{mg} / \mathrm{l})$ and the least pathogenic isolate $\mathrm{SS} 2$ produced its lowest amounts $(2.46 \mathrm{mg} / \mathrm{l})$. Moderately pathogenic isolates were characterized by moderate oxalic acid production within the range of $3.33-3.68 \mathrm{mg} / \mathrm{l}$.

However, not only the oxalic acid in S. sclerotiorum is associated with virulence. The research of Xu et al. (2018) showed that genetically defined mutants that lost oxalic acid production but accumulated fumaric acid could cause disease on many plants.

S. sclerotiorum fungus is very diverse genetically. The presented study used RAPD technique, which is relatively easy and inexpensive, and applies an amplification of random fragments of genomic DNA using primers with a length of 10-20 base pairs. This results in unique sets of striations (amplicons) in agarose gel appropriate for a given genotype, which allow to detect differences between the tested objects at the DNA level (Matuszczak 2013). It is important to take into account only clear striations in this method, because the disadvantage of this analysis is its poor repeatability (Ellsworth et al. 1993; Khandka et al. 1997; Perez et al. 1998).

Attempts of $S$. sclerotiorum population analysis using RAPD usually shows only a large variety of pathogen isolates with no connection to a specific trait, such as origin or pathogenicity. Such conclusions were reached by, inter alia, Colagar et al. (2010) who investigated 12 fungus isolates from Canola oilseed rape from different provinces of Iran. In total, they used 18 primers, but according to the authors only 3 differentiated the pathogen most (Ar081, Ar173, Ar0R2). These three selected primers amplified a total of 284 DNA fragments, the size of which ranged from 80 to $3000 \mathrm{bp}$. The created similarity dendrogram ordered the majority of $S$. sclerotiorum isolates in different groups, proving the great genetic diversity between the studied isolates. It was found that RAPD markers used in this study may be a useful tool to study genetic differences between pathogen isolates, but these differences do not have a significant connection with their geographical location. Similarly, the range of genetic diversity of $17 \mathrm{~S}$. sclerotiorum isolates using RAPD analysis was determined in India (Sharma et al. 2013). As many as 50 primers were used for the analyses, and 692 amplicons of 190-3600 bp size were obtained in total, of which 385 were polymorphic. On the basis of the similarity coefficient in the range of $0.18-0.87$, a dendrogram with four main clusters was created. Comparable results of the similarity coefficient according to Nei and Li were obtained in the present study, which was at the level of $0.2-0.9$ for isolates from 2012 and 2013 and $0.1-0.9$ for isolates from 2014. Also in the study of isolates of S. sclerotiorum from different hosts (beans, tomatoes, peppers, peas, lettuce, sunflower, carrots, radishes, rape, cabbage) and from different regions of Brazil using RAPD with 16 primers, the genetic differences obtained were not related to the host or geographical origin (Litholdo Júnior et al. 2011). Furthermore, the AMOVA statistical analysis showed $99.1 \%$ differentiation between pathogen isolates in geographical regions, and only $0.89 \%$ were related to differences between isolates from a given host. In this study, using 12 RAPD primers, a large diversity of isolates of $S$. sclerotiorum was found every year. Further analysis of similarities according to Nei and Li allowed to group the population of pathogen obtained from oilseed rape plants according to their origin. In the presented study, the AMOVA analysis also showed a very large variation within the population from a

Table 7 Molecular variance analysis (AMOVA) based on RAPD markers for S. sclerotiorum isolates obtained from three localities in $2014, p<0.001$

\begin{tabular}{|c|c|c|c|c|c|}
\hline Source & Degrees of freedom & Sum of squares & Mean of squares & Standard deviation & Variance $\%$ \\
\hline Between populations & 2 & 116.359 & 58.180 & 1.280 & $7 \%$ \\
\hline Inside the population & 93 & 1633.391 & 17.563 & 17.563 & $93 \%$ \\
\hline Sum & 95 & 1749.750 & & 18.843 & $100 \%$ \\
\hline
\end{tabular}


given locality at the level of $87 \%$ in 2012, 96\% in 2013 and 93\% in 2014, and between the populations from given localities at the level of $13 \%, 4 \%$ and $7 \%$, respectively.

Partial correlation of RAPD markers with the origin of S. sclerotiorum isolates was found by Mandal and Dubey (2012). In their study of differentiation of 24 isolates isolated mainly from chickpeas, peas and mustard from 10 different states of India with 21 RAPD primers, 109 amplification products were obtained in total, $48.6 \%$ of which were polymorphic. The majority of isolates were similar in $90 \%$. Similar conclusions were reached by Tok et al. (2016). By studying the diversity of 60 isolates of S. sclerotiorum isolated from aubergine from 6 different regions of Turkey using 10 RAPD primers, more than $90 \%$ similarity between the isolates was found. In addition, partial correlation with mycelial compatibility groups as well as with geographical origin and virulence was found.

The applied RAPD analysis with five primers (R1, R2, R3, R4, R5) allowed not only to demonstrate the diversity of S. sclerotiorum isolates, but also to find a correlation between one of the markers and pathogenicity of the pathogen (ELArgawy 2015). R1 and R4 primers showed the highest polymorphism. However, the most effective marker detecting the differences in pathogenicity was R3, which amplified 9 DNA fragments for an isolate producing large amounts of oxalic acid and 4 fragments for an isolate with low ability to produce it. Further analysis of similarities according to Nei and Li and the created dendrogram of similarities confirmed a large genetic difference between the most and least pathogenic isolate, placing both isolates in two extreme clusters. In this study, unfortunately, no links were found between the RAPD primers used and the production of oxalic acid by the collected isolates during three consecutive years.

The characteristics of S. sclerotiorum contained in the above work indicate a high level of differentiation of isolates occurring in Poland in terms of total acid production and genetics. These studies provide to understand of the management strategies for S. sclerotiorum infection and select of representative isolates for host resistance test.

\section{Compliance with ethical standards}

Conflict of interest The authors declare that they have no conflict of interest.

Ethical approval This article does not contain any studies with human participants or animals performed by any of the authors.

Open Access This article is licensed under a Creative Commons Attribution 4.0 International License, which permits use, sharing, adaptation, distribution and reproduction in any medium or format, as long as you give appropriate credit to the original author(s) and the source, provide a link to the Creative Commons licence, and indicate if changes were made. The images or other third party material in this article are included in the article's Creative Commons licence, unless indicated otherwise in a credit line to the material. If material is not included in the article's
Creative Commons licence and your intended use is not permitted by statutory regulation or exceeds the permitted use, you will need to obtain permission directly from the copyright holder. To view a copy of this licence, visit http://creativecommons.org/licenses/by/4.0/.

\section{References}

Basha SA, Sarma BK, Singh KP, Singh UP (2006) Variation in biochemical composition among Indian isolates of Sclerotinia sclerotiorum. Mycobiology 34(3):114-119

Bateman DF, Beer SV (1965) Simultaneous production and synergistic action of oxalic acid and polygalacturonase during pathogenesis by Sclerotinia rolfsii. Phytopathology 55:204-211

Bolland GJ, Hall R (1994) Index of plant hosts of Sclerotinia sclerotiorum. Can J Plant Pathol 16:93-108

Cessna SG, Sears VE, Dickman M, Low PS (2000) Oxalic acid, a pathogenicity factor for Sclerotinia sclerotiorum suppresses the oxidative burst of the host plant. Plant Cell 12:2119-2199

Colagar AH, Saadati M, Zarea M, Talei SA (2010) Genetic variation of the Iranian Sclerotinia sclerotiorum isolates by standardizing DNA polymorphic fragments. Biotechnol. 9:67-72

Durman SB, Menendez AB, Godeas AM (2005) Variation in oxalic acid production and mycelial compatibility within field populations of Sclerotinia sclerotiorum. Soil Biol Biochem 37:2180-2184

EL-Argawy E (2015) Oxalic acid production by Sclerotinia sclerotiorum and its relation to pathogenicity. J. Plant Prot. and Path., Mansoura Univ. 3(3):211-225

Ellsworth DL, Rittenhouse KD, Honeycutt RL (1993) Artifactual variation in randomly amplified polymorphic DNA banding patterns. Biotechniques 14(2):214-217

Fagundes-Nacarath IRF, Debona D, Rodrigues FA (2018) Oxalic acidmediated biochemical and physiological changes in the common bean-Sclerotinia sclerotiorum interaction. Plant Physiology \& Biochemistry 129:109-121

Godoy G, Steadman JR, Dickman MB, Dam R (1990) Use of mutants to demonstrate the role of oxalic acid in pathogenicity of Sclerotinia sclerotiorum on Phaseolus vulgaris. Physiol Mol Plant Pathol 37: 179-191

Guimarães RL, Stotz HU (2004) Oxalate production by Sclerotinia sclerotiorum deregulates guard cells during infection. Plant Physiol 136:3703-3711

Hegedus DD, Rimmer SR (2005) Sclerotinia sclerotiorum: when 'to be or not to be' a pathogen? FEMS Microbiol Lett 251:177-184

Khandka DK, Tuna M, Tal M, Nejidat A, Golan-Goldhirsh A (1997) Variability in the pattern of random amplified polymorphic DNA. Electrophoresis 18(5):2852-2856

Kim KS, Min JY, Dickman MB (2008) Oxalic acid is an elicitor of plant programmed cell death during Sclerotinia sclerotiorum disease development. Mol Plant Microbe Int 21:605-612

Korbas M, Czubiński T, Horoszkiewicz-Janka J, Jajor E, Danielewicz J (2015) Atlas chorób roślin rolniczych dla praktyków. Polskie Wydawnictwo Rolnicze Sp. Z o.o., Poznań 2015 wydanie I, redakcja Top Agrar: 234-236

Kruger W (1973) Control measures for Sclerotinia sclerotiorum in rape. Phytopath Z 77:125-137

Kryczyński S, Weber Z (red.) (2011) Choroby roślin uprawnych. Fitopatologia 2. PWRiL: 386-387

Li GQ, Huang Hung Chang, Ren Li, Huang Juan, Barka EA and Clément C (2008a) Role of oxalic acid in pathogenesis, sclerotial development and management of the plant pathogen Sclerotinia sclerotiorum. In: Plant-microbe interactions (ISBN 978-81-3080212-1): 217-243 
Li Z, Zhang WY, Li R, Dilantha Frernando WG (2008b) Mycelial compatibility group and pathogenicity variation of Sclerotinia sclerotiorum populations in sunflower from China, Canda and England. Plant Pathol J 7(2):131-139

Litholdo Júnior CG, Gomes EV, Lobo Júnior M, Nasser LCB, Petrofeza S (2011) Genetic diversity and mycelial compatibility groups of the plant-pathogenic fungus Sclerotinia sclerotiorum in Brazil. Genet Mol Res 10:868-877

Mandal AK, Dubey SC (2012) Genetic diversity analysis of Sclerotinia sclerotiorum causing stem rot in chickpea using RAPD, ITS-RFLP, ITS sequencing and mycelial compatibility grouping. World Journal of Microbiology and Biotechnology 28(4):1849-1855

Marciano P, Di Lenna P, Magro P (1983) Oxalic acid, cell wall-degrading enzymes and $\mathrm{pH}$ in pathogenesis and their significance in the virulence of two Sclerotinia sclerotiorum isolates on sunflower. Physiol Mol Plant Pathol 22:339-345

Matuszczak M (2013) Markery molekularne w badaniach rzepaku (Brassica napus L.) I. Przegląd stosowanych technik. Rośliny Oleiste-Oilseed Crops XXXIV (2): 129-150

Maxwell DP, Lumsden RD (1970) Oxalic acid production by Sclerotinia sclerotiorum in infected bean and in culture. Phytopathology 60(139):5-1398

Mo M, Li Z, Li R, Chen Y, Fernando DWG (2007) Analysis of mycelial compatibility and pathogenicity of Sclerotinia sclerotiorum isolated from oilseed crops in Canada, China, USA and England. Proceedings of the 12th International Rapeseed Congress, 2630.03., Wuhan, China, 4: 190-193

Morrall RAA, Dueck J, Mc Kenzie DL, McGee DC (1976) Some aspects of Sclerotinia sclerotiorum in Saskatchewan. 1970-75. Can Plant Dis Surv 56:56

Nei M, Li WH (1979) Mathematical model for studying genetic variation in terms of restriction endonucleases. Proc Natl Acad Sci U S A 76: $5269-5273$

Perez T, Albornoz J, Dominguez A (1998) An evaluation of RAPD fragment reproducibility and nature. Mol Ecol 7(10):1347-1357

Sharma P, Meena PD, Kumar S, Chauhan JS (2013) Genetic diversity and morphological variability of Sclerotinia sclerotiorum isolates of oilseed Brassica in India. Afr J Microbiol Res 7(18):1827-1833
Smith VL, Punja ZK, Jenkins SF (1986) A histological study of infection of host tissue by Sclerotinia rolfsii. Phytopathology 76:755-759

Starzycka E, Kachlicki P, Starzycki M (2002) Zróżnicowanie polskich i chińskich izolatów Sclerotinia sclerotiorum (Lib.) de Bary pod względem zdolności do wytwarzania kwasu szczawiowego. Rośliny Oleiste - Oilseed Crops t. XXIII (2): 385-390

Starzycka E, Starzycki M (2011) In vivo and in vitro investigations on $\mathrm{pH}$ changes in winter rape (Brassica napus) under the influence of Sclerotinia sclerotiorum mycotoxin. Phytopathologia 61:45-51

Steadman JR, Marcinkowska J, Rutledge S (1994) A semi-selective medium for isolation of Sclerotinia sclerotiorum. Can J Plant Pathol 16: 68-70

Tok FM, Derviș S, Arslan M (2016) Analysis of genetic diversity of Sclerotinia sclerotiorum from eggplant by mycelial compatibility, random amplification of polymorphic DNA (RAPD) and simple sequence repeat (SSR) analyses. Biotechnology \& Biotechnological Equipment 30(5):921-928

Wang D, Fu J, Zhou R, Li Z, Xie Y, Liu X, Han Y (2018) Formation of sclerotia in Sclerotinia ginseng and composition of the sclerotial exudate. Peer J 6. https://doi.org/10.7717/peerj.6009

Welsh J, McClelland M (1990) Finger printing genomes using PCR with arbitrary primers. Nucleic Acid Research 18(24):7213-7218

Williams B, Kabbage M, Kim HJ, Britt R, Dickman MB (2011) Tipping the balance: Sclerotinia sclerotiorum secreted oxalic acid suppresses host defenses by manipulating the host redox environment. PLoS Pathog 7:e1002107. https://doi.org/10.1371/journal.ppat.1002107

Williams JGK, Kubelik AR, Livak KJ, Rafalski JA, Tingey SV (1990) DNA polymorphisms amplified by arbitrary primers are useful as genetic markers. Nucleic Acid Research 18(22):6531-6535

Xu L, Li G, Jiang D, Chen W (2018) Sclerotinia sclerotiorum: an evaluation of virulence theories. Annu Rev Phytopathol 56(1):311-338

Yang C, Zhang Z, Gao H, Liu M, Fan X (2014) Mechanisms by which the infection of Sclerotinia sclerotiorum (lib.) de Bary affects the photosynthetic performance in tobacco leaves. BMC Plant Biol 14: 240. https://doi.org/10.1186/s12870-014-0240-4

Publisher's note Springer Nature remains neutral with regard to jurisdictional claims in published maps and institutional affiliations. 